\title{
Bioleaching of trace elements and rare earth elements from coal fly ash
}

\author{
Stephen Park ${ }^{1}$ - Yanna Liang ${ }^{2}$ (B)
}

Received: 2 November 2018/Revised: 10 December 2018/Accepted: 12 January 2019/Published online: 23 January 2019

(C) The Author(s) 2019

\begin{abstract}
Coal fly ash originated from coal combustion has high concentrations of metals. If suitable leaching techniques are identified, then coal fly ash could serve as a useful source of valuable minerals including rare earth elements (REEs). In this study, three microbial strains, Candida bombicola, Phanerochaete chrysosporium and Cryptococcus curvatus were tested on their performance of leaching trace elements and REEs from fly ash. Through comparing mineral loss and leaching efficiencies resulting from indirect leaching or use of the culture supernatant, C. bombicola was identified to be the best leading to the highest mineral loss and extracting efficiencies of trace elements and REEs among the three strains. The highest mineral loss observed from using the supernatant of this yeast strain was 59.7\%. Among all trace elements, As and Mo had the highest leaching efficiency of $80.9 \%$ and $79.5 \%$, respectively. The same leaching test led to $67.7 \%$ of $\mathrm{Yb}$ and $64.6 \%$ of Er dissolved from the ash. This study, thus, demonstrated that bioleaching is feasible for leaching metals out of fly ash. The $C$. bombicola strain deserves further investigation due to its robust actions on metal leaching.
\end{abstract}

Keywords Cryptococcus curvatus · Candida bombicola $\cdot$ Phanerochaete chrysosporium · Coal fly ash · Bioleaching · Rare earth elements · Trace metals

Disclaimer This report was prepared as an account of work sponsored by an agency of the United States Government. Neither the United States Government nor any agency thereof, nor any of their employees, makes any warranty, express or implied, or assumes any legal liability or responsibility for the accuracy, completeness, or usefulness of any information, apparatus, product, or process disclosed, or represents that its use would not infringe privately owned rights. Reference herein to any specific commercial product, process, or service by trade name, trademark, manufacturer, or otherwise does not necessarily constitute or imply its endorsement, recommendation, or favoring by the United States Government or any agency thereof. The views and opinions of authors expressed herein do not necessarily state or reflect those of the United States Government or any agency thereof.

Yanna Liang

yliang3@albany.edu

1 Department of Civil and Environmental Engineering, Southern Illinois University Carbondale, 1230 Lincoln Drive, Carbondale, IL 62901, USA

2 Department of Environmental and Sustainable Engineering, State University of New York at Albany, 1400 Washington Ave, Albany, NY 12222, USA

\section{Introduction}

To avoid using toxic chemicals that have been traditionally used in leaching of various metals, research and development on bioleaching or biomining have been on the rise. Bioleaching takes advantage of microbial activities to turn valuable but insoluble metal compounds into water soluble forms. Compared to chemical leaching, this technology has the advantages of being: (1) environmentally friendly, (2) low energy input and (3) low chemical cost. Due to these benefits, bioleaching has been used broadly in recovering metals, such as: $\mathrm{Cu}, \mathrm{Ni}, \mathrm{Cr}, \mathrm{Zn}, \mathrm{Pb}, \mathrm{Cd}, \mathrm{Au}$ from sulfidic low-grade ores (Watling et al. 2014) (Sutar and Awasare 2015), printed circuit boards (Karwowska et al. 2014), and various industrial solid wastes (Karwowska et al. 2015; Mishra and Rhee 2014). It has been estimated that as much as $15 \%$ of copper and $5 \%$ of gold production worldwide utilize microbial-assisted extraction technology (Johnson 2014). In terms of coal and coal related products, 
bioleaching has been demonstrated to be successful in removing $13 \%-66 \%$ of $\mathrm{Mn}, \mathrm{Fe}, \mathrm{Na}, \mathrm{As}, \mathrm{Cd}, \mathrm{Cu}, \mathrm{Ni}, \mathrm{Zn}, \mathrm{Cr}$, $\mathrm{Co}$ and $\mathrm{Pb}$ from Indian coals (Singh et al. 2014, 2015), and leaching at least $70 \%$ of $\mathrm{Cr}, \mathrm{Ni}, \mathrm{As}$, and $\mathrm{Pb}$ from coal fly ash generated in China (Jadhav and Hocheng 2015).

Specific to recovery of rare earth elements (REEs), bioleaching has also been shown to be technically feasible. For example, from Egyptian monazite, $75.4 \%$ and $63.5 \%$ of REEs were leached by Aspergillus ficuum at $30{ }^{\circ} \mathrm{C}$ and Pseudomonas aeruginosa at $35^{\circ} \mathrm{C}$, respectively (Hassanien et al. 2013). In another study, use of the same $A$. ficuum strain dissolved $20 \%$ of La, $33 \%$ of $\mathrm{Ce}$ and $2.51 \%$ of $\mathrm{Y}$ in thorium-uranium concentrate (Desouky et al. 2011). With regard to Uraniferous Gibbsite ore containing 4,900 ppm of REEs, $55.1 \%$ of which was leached by the presence of an Acidithiobacillus ferrooxidans strain cultivated at $30{ }^{\circ} \mathrm{C}$ (Ibrahim and El-Sheikh 2011). Regarding coal ash studied in Russia, through incubation with an acidophilic chemolithotrophic microbial community, $52 \% .0,52.6 \%$, and $59.5 \%$ of Se, Y and La were recovered, respectively (Muravyov et al. 2015). Use of other microbial strains, however, resulted in REE leaching efficiencies of $<0.2 \%$ on Monazite-bearing ore (Shin et al. 2015). Thus, the bioleaching performance is highly dependent on selected microorganisms and may also be specific to target ores.

The mechanisms of bioleaching are set upon at least two facts: (1) the majority of leaching microbes grow attached on mineral surfaces (Schippers et al. 2013). This attachment is mediated by the extracellular polymeric substances (EPSs) that surround the cells. The EPSs can be sugars, lipids, proteins, nucleic acids and the combinations of these. Attachment and/or surface contact can stimulate EPS production by up to 100-fold (Noël et al. 2010; Vandevivere and Kirchman 1993); and (2) once cells are attached to minerals, they secrete organic acids, amino acids, peptides, lipids, enzyme complexes or even cyanide ions (Willscher and Bosecker 2003). Organic acids are recognized as the most important leaching agents in bioleaching processes using fungi and bacteria (Yang et al. 2008). The most observed acids are citric, oxalic, tartaric and gluconic. Organic acids promote mineral dissolution by: (1) donating $\mathrm{H}^{+}$to proton-promoted dissolution processes; (2) forming inner-sphere surface complexes that dislodge structural metals from the mineral surface; and (3) the formation of aqueous metal-ligand complexes that reduce the relative solution saturation with respect to minerals undergoing dissolution (Goyne et al. 2010).

In view of these mechanisms, we aimed to investigate three microbial strains on their performance of leaching metals from coal fly ash. Recovering metals from ash takes into consideration of: (1) while coal fly ash is a waste product from coal combustion, this material is enriched with minerals, such as trace elements and REEs; (2) metals, especially REEs including the 15 lanthanides plus yttrium and scandium (Lin et al. 2017) are valuable and extraordinarily useful elements for our society (Hower et al. 2016). REEs have broad uses in clean energy production, health care, automotive, electronics, and defense industries. Therefore, extracting metals from coal ash generates valuables for the society from a waste material. The rationale for studying three microbial strains are: (1) Phanerochaete chrysosporium belongs to wood-decay basidiomycetes, collectively referred to as white rot fungi (Fernandez-Fueyo et al. 2012). Phanerochaete chrysosporium was the first basidiomycete where lignin peroxidase and manganese peroxidase were discovered from (Fakoussa and Hofrichter 1999). In one study, after 16 days, this fungus was found to convert $85 \%$ of low rank coal to a form which was not recoverable by alkali washing and acid precipitation (Ralph and Catcheside 1994); (2) Candida bombicola is a non-pathogenic yeast strain and has the ability in producing sophorolipids which are surface active biocompounds (Samad et al. 2015, 2017). The highest yield of $422 \mathrm{~g} / \mathrm{L}$ was observed when deproteinized whey and rapeseed oil were used as substrates for $C$. bombicola (Daniel et al. 1998); (3) Cryptococcus curvatus is an oleaginous yeast whose capability in accumulating intracellular lipids was demonstrated by our and numerous other researchers' studies. In particular, this yeast strain can grow on hydrolysates derived from plant biomass, which may contain a suite of toxic or inhibitory compounds (Liang et al. 2012, 2014a, b); (4) besides being robust, the commonality among the three is that during fermentation, the $\mathrm{pH}$ of the culture decreases, which may indicate the release of organic acids. And all three cultures can tolerate low $\mathrm{pH}$ between 3 and 4; and (5) none of these strains have been tested for leaching metals from coal fly ash.

\section{Materials and methods}

\subsection{Microorganisms and inoculum preparation}

White rot fungus, the basidiomycete, Phanerochaete chrysosporium (ATCC 24725) was grown in a liquid medium made from a recipe reported in (Tien and Kirk 1988). Briefly, the medium contained (per liter) of $100 \mathrm{~mL}$ of Basal II medium, $100 \mathrm{~mL}$ of $10 \%$ glucose, $100 \mathrm{~mL}$ of 0.1 M 2,2-dimethylsuccinate (pH 4.2), $10 \mathrm{~mL}$ of $100 \mathrm{mg} / \mathrm{L}$ of thiamin, $25 \mathrm{~mL}$ of $8 \mathrm{~g} / \mathrm{L}$ of ammonium tartrate, $100 \mathrm{~mL}$ of veratryl alcohol and $60 \mathrm{~mL}$ trace elements. A yeast strain, Candida (Starmerella) bombicola (ATCC 22214) was maintained on agar plates containing (per liter): glucose, $100 \mathrm{~g}$; yeast extract, $10 \mathrm{~g}$; urea, $1 \mathrm{~g}$; and agar, $20 \mathrm{~g}$. Colonies were transferred to fresh plates every 6 weeks and 
were used to start inoculum in the same medium but without agar (Samad et al. 2015). Another yeast strain, Cryptococcus curvatus (ATCC 20509) was set up by adding frozen stock of this yeast to a medium containing yeast extract (10 g/L), peptone (20 g/L), and glucose (10 g/ $\mathrm{L})$. For each of these cultures, the $\mathrm{pH}$ of the growth medium was adjusted to 5.5 using $\mathrm{HCl}$ or $\mathrm{NaOH}$. All liquid cultures were maintained in a shaking incubator at $120 \mathrm{rpm}$ and $28^{\circ} \mathrm{C}$.

\subsection{Coal fly ash}

The fly ash was obtained from the combustion of coal at the Southern Illinois University Carbondale power plant. The collected ash was ground in a ball mill for $1 \mathrm{~h}$ and sieved through a 200 mesh, where particles less than $74 \mu \mathrm{m}$ were used in this study. The fly ash at the designated size was characterized in terms of moisture content and mineral content. For the former, the samples were dried in an oven at $103{ }^{\circ} \mathrm{C}$ until constant weight. For the latter, the dried samples were placed in a furnace at $550{ }^{\circ} \mathrm{C}$ for $6 \mathrm{~h}$. To avoid confusion, the content of those incombustible materials was termed as content of minerals instead of content of ash since fly ash was investigated here.

\subsection{Bioleaching experiments}

Fly ash leaching was conducted by using supernatant as indicated in Fig. 1. Firstly, the microbial cells were revived from corresponding frozen stocks stored at $-80{ }^{\circ} \mathrm{C}$. Secondly, the revived cells at $10 \%$ of the final culture volume were grown on fly ash at $1 \%(\mathrm{w} / \mathrm{v})$ in the standard medium detailed above for three days. During the fermentation period, the cultures were maintained at $28{ }^{\circ} \mathrm{C}$ in darkness with shaking at $150 \mathrm{rpm}$. The cultures were monitored closely on a daily basis for cell growth by measuring optical density at $600 \mathrm{~nm}$ using a spectrophotometer and
$\mathrm{pH}$ using a $\mathrm{pH}$ meter. After three days, the whole culture was centrifuged at 4,500g for $15 \mathrm{~min}$ to separate solid from liquid. The liquid portion, termed as supernatant was used to leach fresh fly ash. This leaching was conducted at $28{ }^{\circ} \mathrm{C}$ for $6 \mathrm{~h}$ with shaking at $50 \mathrm{rpm}$. After $6 \mathrm{~h}$, the solid was separated from the liquid by filtration through a 0.45 $\mu \mathrm{m}$ membrane filter. The solid was then washed with $50 \mathrm{~mL}$ of distilled and deionized water (DDW), dried in an oven at $105{ }^{\circ} \mathrm{C}$ until constant weight to measure total solid content, and subsequently put in a $550{ }^{\circ} \mathrm{C}$ muffle furnace for $6 \mathrm{~h}$ to measure inorganic mineral content. The residual minerals were then analyzed by ICP-MS for quantifying individual metal content. It needs to be noted that all of these experiments were performed for each of the three target microorganisms (Fig. 1) and all experiments were conducted with three replicates. Again, since fly ash contained both minerals and volatile materials, the term of mineral loss was used instead of ash loss to count for those losses contributed by minerals or metals only. In addition to the supernatant, DDW and each growth medium were used to leach fly ash, too.

\subsection{ICP-MS}

Metals including REEs were analyzed by following procedures outlined in EPA method 200.8, Revision 5.4: Determination of Trace Elements in Waters and Wastes by Inductively Coupled Plasma-Mass Spectrometry (ICPMS). Briefly, both fly ash and residual ash samples after $550{ }^{\circ} \mathrm{C}$ in a furnace were subjected to this analysis. The samples were digested in a diluted mixture of nitric acid and hydrochloric acid for reflux extraction of the analytes at $95{ }^{\circ} \mathrm{C}$ for $30 \mathrm{~min}$. After cooling to room temperature, the samples were diluted and analyzed by ICP-MS. Metals were quantified based on calibration curves established for mixtures of trace elements listed in Method 200.8 and those of REEs.

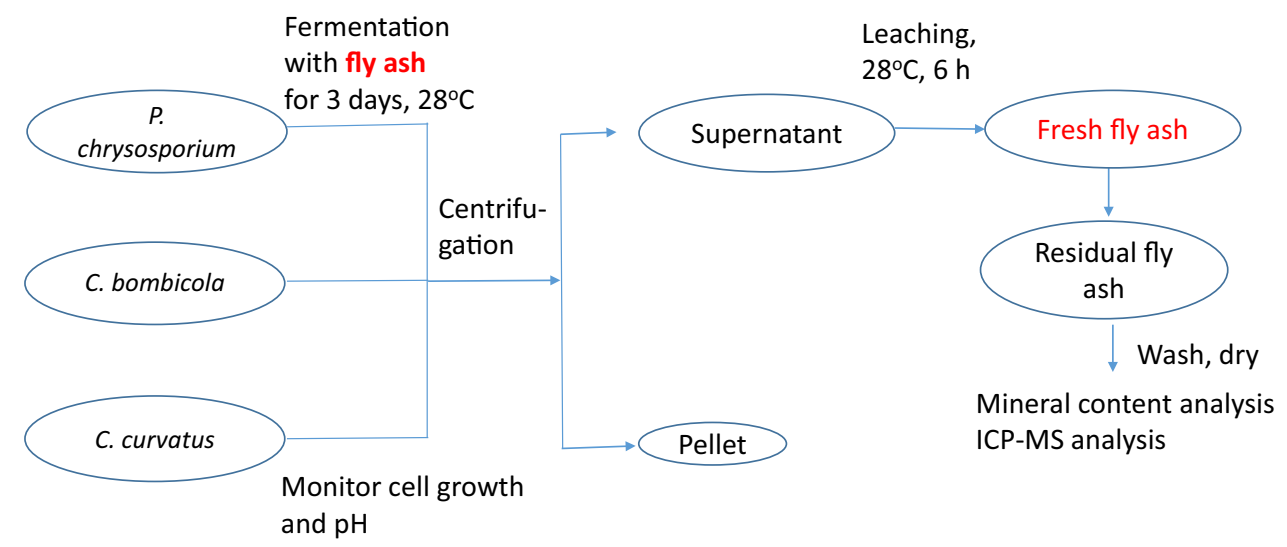

Fig. 1 The overall experimental design 


\section{Results and discussion}

As discussed above, bioleaching has been performed through using different microorganisms. But for the three targeted here, no studies have been conducted yet. Since this is the first bioleaching study on the three strains, our initial questions were: (1) Can these three microorganisms leach metals out of the fly ash? (2) If yes, which one is the best? And (3) What are the efficiencies in leaching different metals? To answer these unknowns, we took a down select approach. At the beginning, all three microbes were cultivated simultaneously in specific standard medium with fly ash as shown in Fig. 1. Based on mineral loss and metals' leaching efficiencies, one microorganism was studied further.

As described above, the mineral loss $(\%)=[($ total minerals in the initial fly ash) - (total minerals in the residual fly ash)]/total minerals in the initial fly ash $x$ $100 \%$. In this case, the mineral is the same as total metals. We used the term minerals instead of ash to avoid confusion since fly ash was the initial substrate. In addition, the fly ash we used contained $85.2 \%$ of minerals or metals.

To measure mineral loss, we could directly measure metal concentrations in the leaching liquid. We chose instead to measure metal contents in the initial and final ash. By doing so, we eliminated the need to consider metal recovery efficiency by using EPA method 200.8 since all solid samples would go through the same extraction procedure: solubilization by gentle refluxing with nitric and hydrochloric acids.

In this study, only the performance of the supernatant in metal leaching was investigated. This is also referred to indirect or two-step leaching compared to direct or onestep leaching by using microbial cells (Brandl et al. 2001). This approach considered the difficulty in separating cells from residual fly ash. In particular, if fungi are used, leached metals are often adsorbed to or enclosed by the fungal mycelium (Jain and Sharma 2004) (Hopfe et al. 2017), which makes separating residual solid substrates from fungal biomass nearly impossible. Thus, for the three heterotrophic microorganisms, the strategy we used was to grow the microbes first and then use the metabolites in the supernatant for quantitative leaching.

The fly ash used in this study had a moisture content of $0.419 \% \pm 0.039 \%$ (wet weight based). The mineral content was $0.852 \pm 0.002 \mathrm{~g} / \mathrm{g}$, dry weight (dw) based. Thus, the content of volatile matter was $0.148 \mathrm{~g} / \mathrm{g}$ ( $\mathrm{dw}$ based). The major trace elements detected in the fly ash were (Table 1): Fe: 62.02 g/kg; Al: 46.72 g/kg; Zn: 240.37 mg/ $\mathrm{kg}$; V: $104.30 \mathrm{mg} / \mathrm{kg}$; Ba: $99.31 \mathrm{mg} / \mathrm{kg}$; Mn: $94.09 \mathrm{mg} / \mathrm{kg}$; and $\mathrm{Pb}: 86.52 \mathrm{mg} / \mathrm{kg}$. The other 14 had content lower than $50 \mathrm{mg} / \mathrm{kg}$. Among REEs, the dominant ones were: $\mathrm{Ce}$,
Table 1 Elemental composition of fly ash

\begin{tabular}{|c|c|}
\hline Metal & Content $(\mathrm{dw})[\mathrm{mg} / \mathrm{kg}]$ \\
\hline $\mathrm{Be}$ & 9.17 \\
\hline $\mathrm{Al}$ & 46721.54 \\
\hline V & 104.30 \\
\hline $\mathrm{Cr}$ & 53.77 \\
\hline $\mathrm{Mn}$ & 94.09 \\
\hline $\mathrm{Fe}$ & 62021.68 \\
\hline Co & 14.18 \\
\hline $\mathrm{Ni}$ & 43.43 \\
\hline $\mathrm{Cu}$ & 48.60 \\
\hline $\mathrm{Zn}$ & 240.37 \\
\hline As & 4.62 \\
\hline $\mathrm{Se}$ & 17.77 \\
\hline Mo & 8.18 \\
\hline $\mathrm{Ag}$ & 0.23 \\
\hline $\mathrm{Cd}$ & 3.82 \\
\hline $\mathrm{Sb}$ & 0.27 \\
\hline $\mathrm{Ba}$ & 99.31 \\
\hline $\mathrm{Tl}$ & 0.14 \\
\hline $\mathrm{Pb}$ & 86.52 \\
\hline Th & 8.43 \\
\hline $\mathrm{U}$ & 7.05 \\
\hline $\mathrm{Sc}$ & 16.7 \\
\hline $\mathrm{Y}$ & 26 \\
\hline $\mathrm{La}$ & 22.9 \\
\hline $\mathrm{Ce}$ & 47.3 \\
\hline $\operatorname{Pr}$ & 5.5 \\
\hline $\mathrm{Nd}$ & 21.1 \\
\hline $\mathrm{Sm}$ & 4.8 \\
\hline $\mathrm{Eu}$ & 1.1 \\
\hline $\mathrm{Gd}$ & 4.6 \\
\hline $\mathrm{Tb}$ & $<1$ \\
\hline Dy & 4.2 \\
\hline Ho & $<1$ \\
\hline $\mathrm{Er}$ & 2.2 \\
\hline $\mathrm{Yb}$ & 1.9 \\
\hline $\mathrm{Th}$ & 6.7 \\
\hline $\mathrm{Lu}$ & $<1$ \\
\hline $\mathrm{Tm}$ & $<1$ \\
\hline
\end{tabular}

$47.3 \mathrm{mg} / \mathrm{kg}$; Y: $26.0 \mathrm{mg} / \mathrm{kg}$; La, $22.9 \mathrm{mg} / \mathrm{kg}$; Nd, $21.1 \mathrm{mg} /$ $\mathrm{kg}$; and Sc: $16.7 \mathrm{mg} / \mathrm{kg}$. The other $12 \mathrm{had}$ concentrations lower than $10 \mathrm{mg} / \mathrm{kg}$.

After mixing fresh fly ash with supernatant at $28^{\circ} \mathrm{C}$, $50 \mathrm{rpm}$ for $6 \mathrm{~h}$, significant loss of minerals was observed. Regarding $C$. bombicola, the mineral loss was $59.74 \% \pm 1.07 \%$ of those initially in the fly ash. For $P$. chrysosporium supernatant, it was $51.28 \% \pm 3.63 \%$. In 


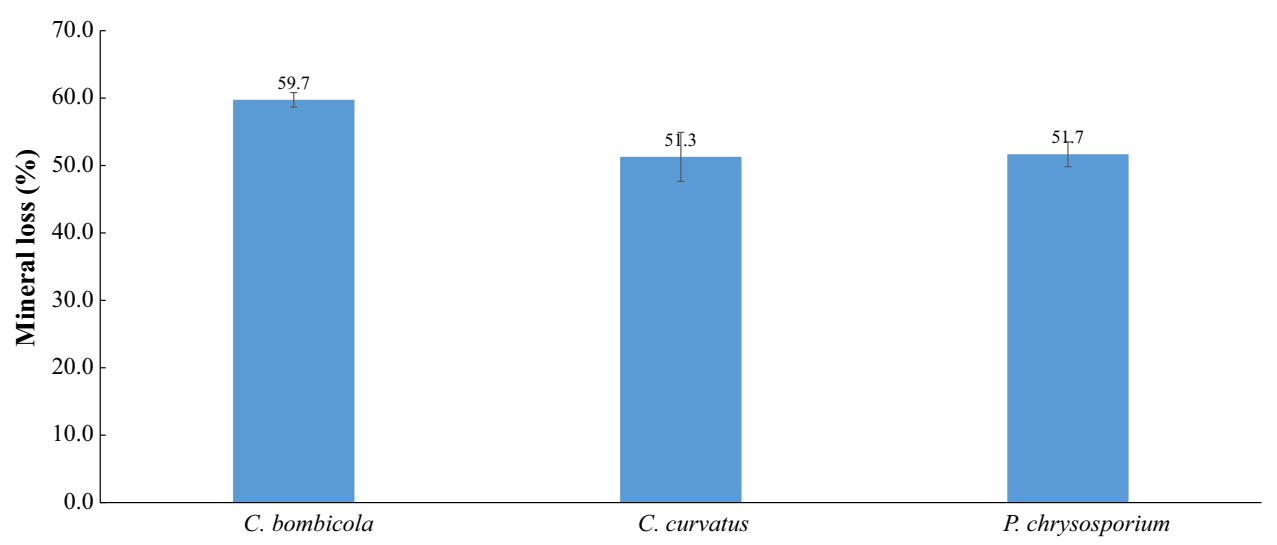

Fig. 2 Mineral loss resulting from using supernatant for leaching fresh fly ash
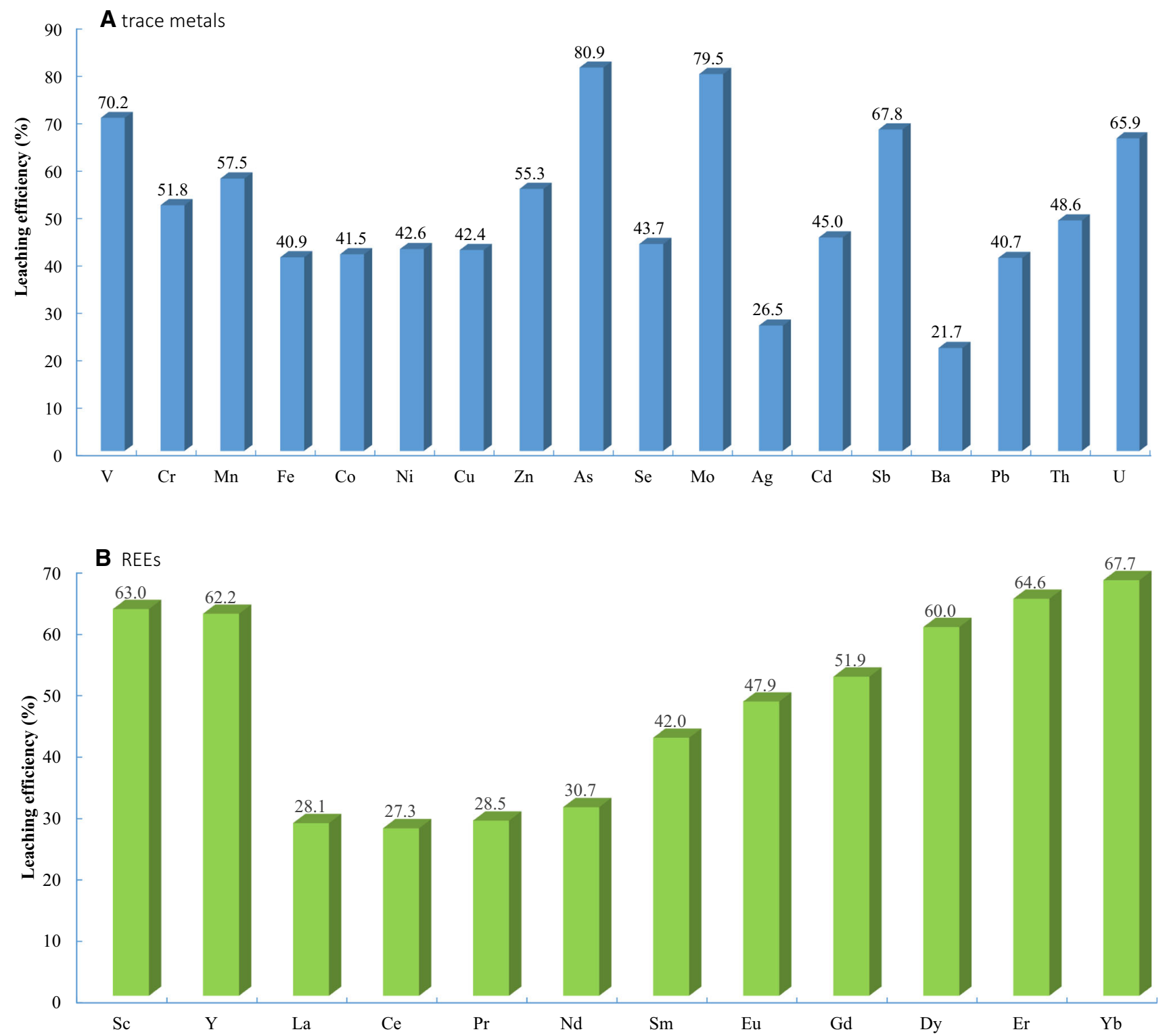

Fig. 3 Leaching efficiency of $C$. bombicola. a Trace metals; b REEs 
terms of C. curvatus, it was $51.66 \% \pm 1.84 \%$ (Fig. 2). After processing the remaining ash in a muffle furnace at $550{ }^{\circ} \mathrm{C}$, the left material referred to as residual mineral was analyzed by ICP-MS. Based on calibration curves built for trace elements and REEs, all metals were quantified. As indicated in Fig. 3, the leaching efficiency of trace elements by $C$. bombicola supernatant varied between $21.7 \%$ and $80.9 \%$. Metals, such as $\mathrm{Ba}$ and $\mathrm{Ag}$ had the lowest extraction efficiency while As and Mo had the highest. With regard to REEs, the loss of $\mathrm{La}, \mathrm{Ce}, \mathrm{Pr}$ and $\mathrm{Nd}$ was the lowest, ranging between $28.1 \%$ and $30.7 \%$. The highest loss was for $\mathrm{Yb}(67.7 \%), \mathrm{Er}(64.6 \%), \mathrm{Sc}(63.0 \%)$ and $\mathrm{Y}$ (62.2\%). In terms of P. chrysosporium (Fig. 4), among trace elements, As and $\mathrm{V}$ had the largest extraction efficiency of $76.8 \%$ and $65.2 \%$, respectively while $\mathrm{Ag}$ and Co had the lowest of around $20 \%$. For REEs, Yb, Sc, Er and Dy had the highest loss in the range of $47 \%-50.6 \%$. Similar to C. bombicola supernatant, $\mathrm{La}, \mathrm{Ce}, \mathrm{Pr}$ and $\mathrm{Nd}$ were leached the least with losses between $22.3 \%$ and $26.0 \%$. Regarding C. curvatus, the highest leaching efficiency was observed for As (75.2\%) and Mo (72.6\%) and the lowest was for $\mathrm{Ba}(8.3 \%)$ among trace elements. Among REEs, the highest loss was detected for $\mathrm{Yb}$ (56.1\%), $\mathrm{Er}(53.2 \%), \mathrm{Sc}(52.1)$ and Dy $(52.1 \%)$. The lowest loss was again for $\mathrm{Ce}, \mathrm{La}, \mathrm{Pr}$, and $\mathrm{Nd}$ in the range of $19.5 \%$ and $24.4 \%$ (Fig. 5).

Comparing leaching results from using the supernatant derived from the three microbial strains, the exaction
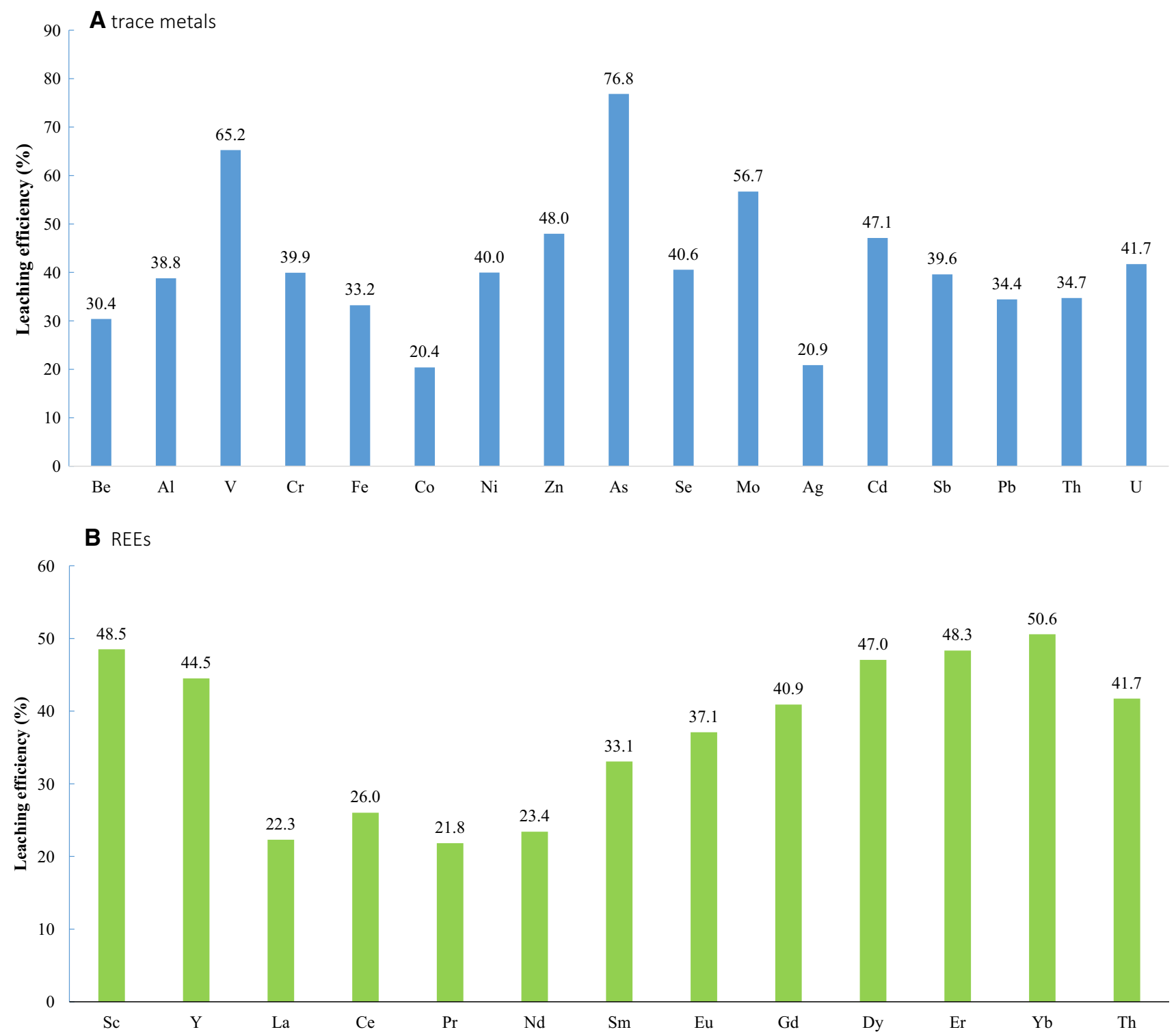

Fig. 4 Leaching efficiency of $P$. chrysosporium. a Trace metals; b REEs 

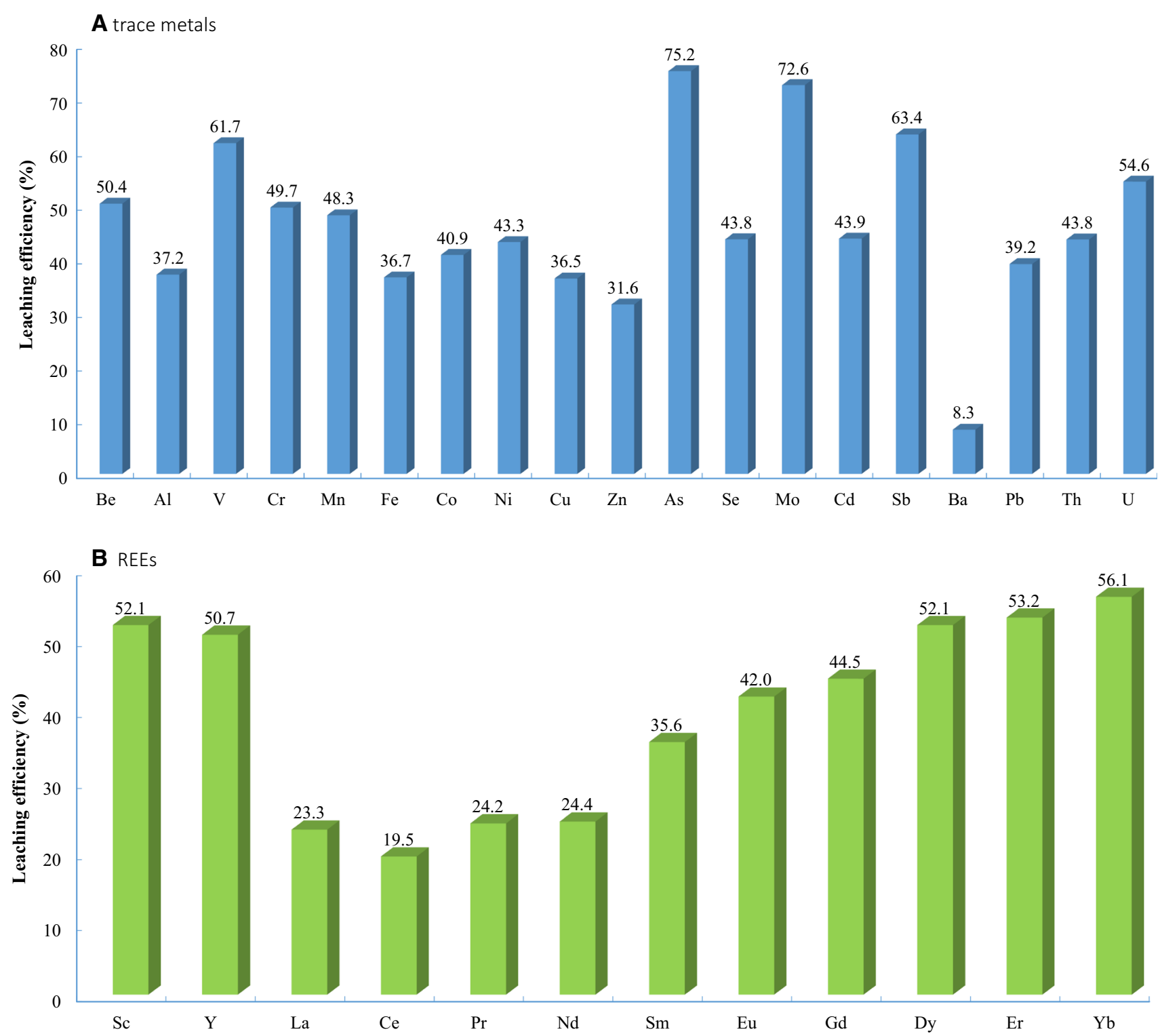

Fig. 5 Leaching efficiency of $C$. curvatus. a Trace metals; b REEs

profile of trace elements was different (Figs. 3a, 4a and 5a), but As and Mo had the highest loss and $\mathrm{Ag}$ and $\mathrm{Ba}$ had the lowest for all of the three strains. The leaching profile of REEs (Figs. $3 b, 4 b$ and $5 b$ ) was very similar although the exact extraction efficiency was different.

Based upon all of these results, we concluded that $C$. bombicola was the best microorganism for leaching metals out of fly ash. To understand whether fermentation time had an effect on leaching, $C$. bombicola was cultivated in the standard medium with fly ash for 3, 6, or 9 days. During fermentation, compared with controls without fly ash, the presence of fly ash did lead to decreased cell growth as reflected from lower optical density (OD). But, the extent of $\mathrm{pH}$ decrease was similar between those two sets (Fig. 6). Supernatant from those with fly ash was also used to leach fresh fly ash. As demonstrated by Fig. 7, fermentation broth from longer cultivation time did not lead to statistically higher leaching efficiencies. Therefore, for achieving the highest leaching efficiencies, a fermentation period of 3 days is enough.

Candida bombicola is known to tolerate low $\mathrm{pH}$. For the purpose of producing sophorolipids-compounds comprising a sophorose head whose reducing end is connected to a terminally or subterminally hydroxylated fatty acid through a beta-glycosidic bond (Ciesielska et al. 2014), the culture $\mathrm{pH}$ is normally maintained at 3.3-3.5 (Davila et al. 1997; Pekin et al. 2005; Daniel et al. 1998; Solaiman et al. 2004). The $\mathrm{pH}$ decrease could be due to the addition of a fatty acid which is a co-substrate for sophorolipid synthesis and/or autoacidification (Rau et al. 2001). For the latter when a 


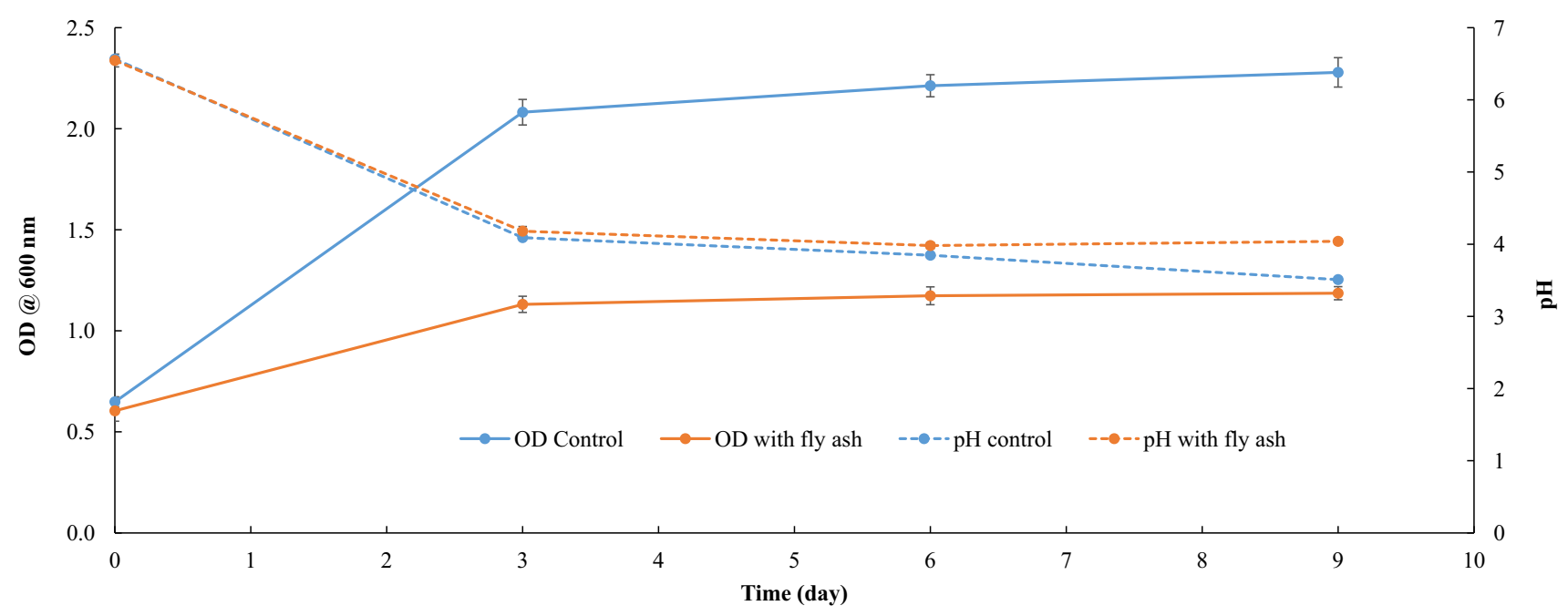

Fig. 6 Candida bombicola growth and $\mathrm{pH}$ change with time

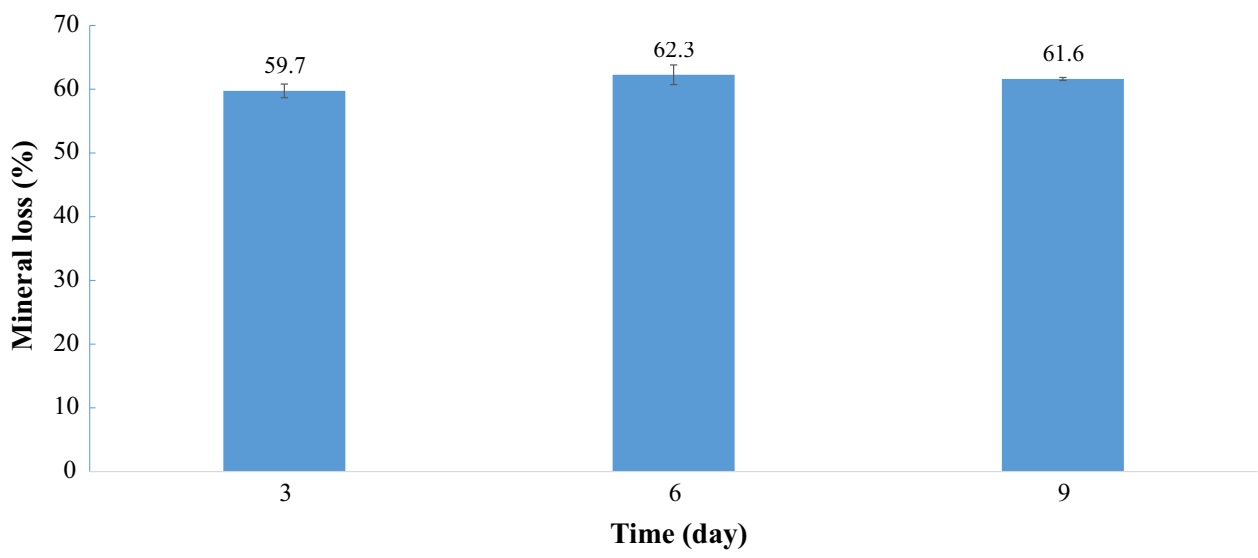

Fig. 7 Leaching efficiency of $C$. bombicola broth on fresh fly ash-effect of fermentation time

fatty acid, such as oleic acid is not used, the $\mathrm{pH}$ decrease could be explained by the formation of acidic sophorolipids versus lactonic forms or the release of other organic acids. However, although production of acidic sophorolipids has been reported by different studies, whose concentration depends on the specific fermentation condition, formation of other organic acids by $C$. bombicola has not been disclosed yet. The similar leaching profile of REEs by the three tested microorganisms suggest that the leaching agents released by the three may be similar in properties. However, further research is warranted to isolate and characterize the chemicals that are responsible for metalleaching.

The leaching efficiencies obtained for the three microorganisms were similar to the highest ones reported and much higher than the others (Table 2). The highest REE extraction efficiency of $75.4 \%$ was attained from Monazite by use of Aspergillus ficuum (Hassanien et al. 2013). In the same study, by using Pseudomonas aeruginosa, the REE leaching efficiency was $63.5 \%$. The only study that focused on coal ash was reported by Muravyov et al. (2015) where leaching efficiency of three REEs were listed. All other studies have target different raw materials (Desouky et al. 2011; Ibrahim and El-Sheikh 2011; Shin et al. 2015) and the results are difficult to be compared.

Although significant amounts of trace elements and REEs were leached by the studied microbial strains in this study, several questions still remain. For example, what are the optimal condition for leaching metals from fly ash? What are the mechanisms involved in such leaching? Can the leaching process be controlled to dissolve specific metals of interest? And can this bioleaching process through using heterotrophs be scaled up at commercial levels? To answer these questions, in-depth studies must be performed. 
Table 2 Comparison of leaching efficiency among different studies

\begin{tabular}{|c|c|c|c|c|c|c|c|}
\hline Microorganism & Raw material & $\begin{array}{l}\text { Temperature } \\
\left({ }^{\circ} \mathrm{C}\right)\end{array}$ & $\begin{array}{l}\text { Duration } \\
\text { (d) }\end{array}$ & $\begin{array}{l}\text { Pulp } \\
\text { density } \\
(\%)\end{array}$ & $\begin{array}{l}\text { Shaking } \\
\text { speed } \\
(\mathrm{rpm})\end{array}$ & $\begin{array}{l}\text { Leaching efficiency } \\
(\%)\end{array}$ & References \\
\hline $\begin{array}{l}\text { Acidophilic } \\
\text { chemolithotrophic } \\
\text { community }\end{array}$ & Ash-slug waste & 45 & 10 & 10 & NA & $\begin{array}{l}\text { Sc: } 52.0 \%, \mathrm{Y}: 52.6 \% \\
\text { La: } 59.5 \%\end{array}$ & $\begin{array}{l}\text { Muravyov et al. } \\
\text { (2015) }\end{array}$ \\
\hline Aspergillus ficuum & Monazite & 30 & 9 & 0.6 & NA & $75.4 \%$ of REEs & $\begin{array}{l}\text { Hassanien et al. } \\
\text { (2013) }\end{array}$ \\
\hline Pseudomonas aeruginosa & & 35 & 8 & 0.6 & 175 & 63.5 REEs & \\
\hline Aspergillus ficuum & $\begin{array}{l}\text { Thorium-uranium } \\
\text { concentrate }\end{array}$ & 28 & 1 & 0.75 & 175 & $\begin{array}{l}\text { La } 20 \% \text {; Ce } 33.0 \% \text {; } \\
\text { Y: } 2.51 \%\end{array}$ & $\begin{array}{l}\text { Desouky et al. } \\
\text { (2011) }\end{array}$ \\
\hline $\begin{array}{l}\text { Acidithiobacillus } \\
\text { ferrooxidans }\end{array}$ & $\begin{array}{l}\text { Uraniferous } \\
\text { Gibbsite ore }\end{array}$ & NA & $\begin{array}{l}30 \\
\text { Cycles }\end{array}$ & NA & NA & $67.58 \%$ of REEs & $\begin{array}{l}\text { Ibrahim and El- } \\
\text { Sheikh (2011) }\end{array}$ \\
\hline Acetobacter aceti & $\begin{array}{l}\text { Monazite bearing } \\
\text { ore }\end{array}$ & 30 & 9 & 16.7 & 180 & $\begin{array}{l}\text { Ce: } 0.13 \% \text {; La: } \\
\quad 0.11 \%\end{array}$ & Shin et al. (2015) \\
\hline Candida bombicola & Coal fly ash & 28 & $6 \mathrm{~h}^{\mathrm{a}}$ & 1 & 50 & $\begin{array}{l}\text { Yb: } 67.7 \% \text {; Er: } \\
\quad 64.6 \% \text {; Sc: } 63.0 \%\end{array}$ & This study \\
\hline
\end{tabular}

${ }^{a}$ Supernatant from the culture was used for leaching

\section{Conclusion}

This study demonstrated that recovering trace elements and REEs from coal fly ash through bioleaching is possible through using different microorganisms. Among the three tested, the fermentation broth of $C$. bombicola gave the highest leaching efficiency of $59.7 \%$. But comparing the results from the three microorganisms, it is interesting that the leaching profiles of REEs were similar. Certain REEs, such $\mathrm{Yb}, \mathrm{Er}, \mathrm{Sc}$ and $\mathrm{Y}$ had the highest loss independent of the culture supernatant used. The mechanisms of bioleaching warrant further investigation. Given the promising results obtained from this study and the low cost feature of bioleaching, this approach deserves to be explored further for extracting metals from solid waste materials beyond coal fly ash. By doing so, we can achieve the dual purposes of waste minimization and resource recovery.

Acknowledgement We gratefully acknowledge support from the Department of Energy of the United States under Award No. DEFE0024126.

Open Access This article is distributed under the terms of the Creative Commons Attribution 4.0 International License (http://creative commons.org/licenses/by/4.0/), which permits unrestricted use, distribution, and reproduction in any medium, provided you give appropriate credit to the original author(s) and the source, provide a link to the Creative Commons license, and indicate if changes were made.

\section{References}

Brandl H, Bosshard R, Wegmann M (2001) Computer-munching microbes: metal leaching from electronic scrap by bacteria and fungi. Hydrometallurgy 59(2):319-326
Ciesielska K, Van Bogaert IN, Chevineau S, Li B, Groeneboer S, Soetaert W, Van de Peer Y, Devreese B (2014) Exoproteome analysis of Starmerella bombicola results in the discovery of an esterase required for lactonization of sophorolipids. J Proteom 98:159-174

Daniel H-J, Reuss M, Syldatk C (1998) Production of sophorolipids in high concentration from deproteinized whey and rapeseed oil in a two stage fed batch process using Candida bombicola ATCC 22214 and Cryptococcus curvatus ATCC 20509. Biotechnol Lett 20(12):1153-1156

Davila A-M, Marchal R, Vandecasteele J-P (1997) Sophorose lipid fermentation with differentiated substrate supply for growth and production phases. Appl Microbiol Biotechnol 47(5):496-501

Desouky OA, El-Mougith AA, Hassanien WA, Awadalla GS, Hussien SS (2011) Extraction of some strategic elements from thoriumuranium concentrate using bioproducts of Aspergillus ficuum and Pseudomonas aeruginosa. Arab J Chem 9:S795-S805

Fakoussa R, Hofrichter M (1999) Biotechnology and microbiology of coal degradation. Appl Microbiol Biotechnol 52(1):25-40

Fernandez-Fueyo E, Ruiz-Dueñas FJ, Ferreira P, Floudas D, Hibbett DS, Canessa P, Larrondo LF, James TY, Seelenfreund D, Lobos S (2012) Comparative genomics of Ceriporiopsis subvermispora and Phanerochaete chrysosporium provide insight into selective ligninolysis. Proc Natl Acad Sci 109(14):5458-5463

Goyne KW, Brantley SL, Chorover J (2010) Rare earth element release from phosphate minerals in the presence of organic acids. Chem Geol 278(1):1-14

Hassanien WAG, Desouky OAN, Hussien SSE (2013) Bioleaching of some rare earth elements from Egyptian monazite using Aspergillus ficuum and Pseudomonas aeruginosa. Walailak $\mathrm{J}$ Sci Technol (WJST) 11(9):809-823

Hopfe S, Flemming K, Lehmann F, Möckel R, Kutschke S, Pollmann K (2017) Leaching of rare earth elements from fluorescent powder using the tea fungus Kombucha. Waste Manag 62:211-221

Hower JC, Granite EJ, Mayfield DB, Lewis AS, Finkelman RB (2016) Notes on contributions to the science of rare earth element enrichment in coal and coal combustion byproducts. Minerals 6(2):32 
Ibrahim H, El-Sheikh E (2011) Bioleaching treatment of Abu Zeneima uraniferous gibbsite ore material for recovering $\mathrm{U}$, REEs, Al and Zn: Res. J Chem Sci 1(4):55-66

Jadhav UU, Hocheng H (2015) Analysis of metal bioleaching from thermal power plant fly ash by Aspergillus niger 34770 culture supernatant and reduction of phytotoxicity during the process. Appl Biochem Biotechnol 175(2):870-881

Jain N, Sharma DK (2004) Biohydrometallurgy for nonsulfidic minerals-a review. Geomicrobiol J 21(3):135-144

Johnson DB (2014) Biomining-biotechnologies for extracting and recovering metals from ores and waste materials. Curr Opin Biotechnol 30:24-31

Karwowska E, Andrzejewska-Morzuch D, Łebkowska M, Tabernacka A, Wojtkowska M, Telepko A, Konarzewska A (2014) Bioleaching of metals from printed circuit boards supported with surfactant-producing bacteria. J Hazard Mater 264:203-210

Karwowska E, Wojtkowska M, Andrzejewska D (2015) The influence of metal speciation in combustion waste on the efficiency of $\mathrm{Cu}$, $\mathrm{Pb}, \mathrm{Zn}, \mathrm{Cd}, \mathrm{Ni}$ and $\mathrm{Cr}$ bioleaching in a mixed culture of sulfuroxidizing and biosurfactant-producing bacteria. J Hazard Mater 299:35-41

Liang Y, Tang T, Umagiliyage AL, Siddaramu T, McCarroll M, Choudhary R (2012) Utilization of sorghum bagasse hydrolysates for producing microbial lipids. Appl Energy 91(1):451-458

Liang Y, Jarosz K, Wardlow AT, Zhang J, Cui Y (2014a) Lipid production by Cryptococcus curvatus on hydrolysates derived from corn fiber and sweet sorghum bagasse following dilute acid pretreatment. Appl Biochem Biotechnol 173(8):2086-2098

Liang Y, Peruz I, Goetzelmann K, Trupia S (2014b) Microbial lipid production from pretreated and hydrolyzed corn fiber. Biotechnol Prog 30:945-951

Lin R, Howard BH, Roth EA, Bank TL, Granite EJ, Soong Y (2017) Enrichment of rare earth elements from coal and coal byproducts by physical separations. Fuel 200:506-520

Mishra D, Rhee YH (2014) Microbial leaching of metals from solid industrial wastes. J Microbiol 52(1):1-7

Muravyov M, Bulaev A, Melamud V, Kondrat'eva T (2015) Leaching of rare earth elements from coal ashes using acidophilic chemolithotrophic microbial communities. Microbiology 84(2):194-201

Noël N, Florian B, Sand W (2010) AFM \& EFM study on attachment of acidophilic leaching organisms. Hydrometallurgy 104(3):370-375

Pekin G, Vardar-Sukan F, Kosaric N (2005) Production of sophorolipids from Candida bombicola ATCC 22214 using Turkish corn oil and honey. Eng Life Sci 5(4):357-362

Ralph J, Catcheside D (1994) Decolourisation and depolymerisation of solubilised low-rank coal by the white-rot basidiomycete
Phanerochaete chrysosporium. Appl Microbiol Biotechnol 42(4):536-542

Rau U, Hammen S, Heckmann R, Wray V, Lang S (2001) Sophorolipids: a source for novel compounds. Ind Crops Prod 13(2):85-92

Samad A, Zhang J, Chen D, Liang Y (2015) Sophorolipid production from biomass hydrolysates. Appl Biochem Biotechnol 175(4):2246-2257

Samad A, Zhang J, Chen D, Chen X, Tucker M, Liang Y (2017) Sweet sorghum bagasse and corn stover serving as substrates for producing sophorolipids. J Ind Microbiol Biotechnol 44(3):353-362

Schippers A, Hedrich S, Vasters J, Drobe M, Sand W, Willscher S (2013) Biomining: metal recovery from ores with microorganisms. In Geobiotechnology I (pp. 1-47). Springer, Berlin

Shin D, Kim J, Kim B-S, Jeong J, Lee J-C (2015) Use of phosphate solubilizing Bacteria to leach rare earth elements from monazitebearing ore. Minerals 5(2):189-202

Singh A, Singh P, Kumar A, Yadav A, Singh M (2014) Experimental study on demineralization of coal with Pseudomonas mendocina strain B6-1 bacteria to obtain clean fuel. Energy Explor Exploit 32(5):831-846

Singh A, Singh P, Kumar A, Singh M (2015) Sequestration of metals from coal using bacteria: environmental implications on clean coal energy. Energy Sources Part A Recovery Util Environ Eff 37(13):1432-1439

Solaiman DK, Ashby RD, Nuñez A, Foglia TA (2004) Production of sophorolipids by Candida bombicola grown on soy molasses as substrate. Biotechnol Lett 26(15):1241-1245

Sutar AS, Awasare SD (2015) 2015, Bioleaching of ore using chemolithotrophic microorganisms (Acidithiobacillus ferrooxidans). Int J Res Environ Sci Technol 5(1):14-21

Tien M, Kirk TK (1988) Lignin peroxidase of Phanerochaete chrysosporium. Methods Enzymol 161:238-249

Vandevivere P, Kirchman DL (1993) Attachment stimulates exopolysaccharide synthesis by a bacterium. Appl Environ Microbiol 59(10):3280-3286

Watling H, Collinson D, Fjastad S, Kaksonen A, Li J, Morris C, Perrot F, Rea S, Shiers D (2014) Column bioleaching of a polymetallic ore: effects of $\mathrm{pH}$ and temperature on metal extraction and microbial community structure. Miner Eng 58:90-99

Willscher S, Bosecker K (2003) Studies on the leaching behaviour of heterotrophic microorganisms isolated from an alkaline slag dump. Hydrometallurgy 71(1):257-264

Yang J, Wang Q, Wang Q, Wu T (2008) Comparisons of one-step and two-step bioleaching for heavy metals removed from municipal solid waste incineration fly ash. Environ Eng Sci 25(5):783-789 